\title{
THE APPLICATION OF THE PRINCIPLE OF UTMOST GOOD FAITH IN PYRAMID SCHEME BUSSINES PRACTICE
}

\author{
Tuti Rastuti ${ }^{1}$, Gandhi Pharmacista ${ }^{2}$ \\ 1,2 Faculty of Law, Pasundan University \\ Ituti.rastuti@unpas.ac.id \\ ${ }^{2}$ gandhi.pharmacista@unpas.ac.id
}

\begin{abstract}
This study focuses on the study of media development against misinformation and contains the best elements. This situation has been exploited by the actors / activities that conduct business pyramid scheme invetation. The social growth media plays an important role in the development of the pyramid in which the givers / promoters in attracting the public interest, carried out in a pattern that is shared with the public figures using the ambassador's brand, the notes boost offerees to join other aspects such as legality and prospects social media investment, social media, culture, culture, culture, culture, culture, socialization, promotion, promotion, promotion, promotion, promotion. This study focuses on the study of violations of law against the principle of utmost good faith in the fraudulent practices of pyramid schemes used by the offeror when conducting recruitment. This fraudulent practice in its development uses social media as a misleading means of conveying information. To appeal to a widely used pattern of inviting offeree by accentuating the public figure being brand ambassador, thus boosting offeree trust to join. The objective of the study was to criticize mediamorphosis in eradicating fraudulent pyramid schemes in business investment. This research uses empirical juridical method with normative juridical approach. Observation activities support the search for legal literature. The results show that, (1) misleading information is a violation of the principle of utmost good faiht used when the promoter offers and recruits the offeree into the fraudulent practices of the pyramid scheme business; (2) social media into commodities and promotional support instruments for offerors in the fraudulent practices of pyramid scheme business investments; offeree joins a prominent pyramid promotion scheme without considering the legality and prospects of the investment.
\end{abstract}

Keywords: Mediamorphosis, investment promotion advertising, pyramid scheme eradication, utmost goodfaith

\section{Introduction}

Indonesia is a country with a variety of mediamorphic media. Mediamorphosis is a big enough impact on the sustainability or existence of the media itself to have a massive impact on society (massive). Print media is one media that experienced mediamorphosis. Print media is not extinct just because of the new media, but print media changes and developments follow the conditions and needs of audiences. Mediamorphosis in print media occurs due to convergence, where convergence is a merge between conventional media and new media. Convergence is possible because digital technology transforms the communication medium into a digital era in which various forms of communication are unified over the internet.

Along with the development of technology, pyramid scam is now rife in the online world in various forms (as if) business investment such as the lure of gold investment, forex, stocks, and so forth. They use sophisticated names like sharia business, online marketing, network marketing, chain letters, refferal marketing, affiliate marketing to Multi Level Marketing. These terms are 
indeed marketing efforts used by many legal companies. But fraudsters also use this mode.

The development of media in the delivery of information has been misused. In a pyramid scheme, the media is used as a means of conveying misleading information, so in the realm of law the act can be categorized as having violated the utmost good faith. The development of social media also influences the development of pyramid schemes used by the offeror in attracting the public interest, which is done with the pattern of inviting offeree by highlighting the public figure being brand ambassador, thus boosting the trust of offeree to join without considering other aspects such as legality and prospect than the investment, which in the end developments of social media into commodities and supporting tools for the offeror in recruiting offeree.

The development of the current media brings up the mechanism of content marketing, which can form Pyramid marketing with ease, with the goal to be achieved is a microcontent that nature mengomosikan and carry the conversation, at this level the main target is social media. Microcontent weakness in social media is to find information in detail, because the information is very short and fast, so the information is not submitted thoroughly and accurately. Violation of such information is a violation of the principle of utmost good faith, even in a pyramid scheme containing misleading and deceptive information. Then the level of consumer confidence to trust a product and service is really not easy, so it takes brand ambassador used to attract the offeree.

\section{Problem Statement}

How the violation of utmost good faith principle in advertisement of pyramid business investment promotion media, influences the development of pyramid schemes used by the offeror in attracting the public interest. Is the pattern invites offeree by highlighting the public figure that is used as brand ambassador, thus boosting the trust of offeree to join without considering the aspect of the legality and the prospect of the investment

\section{The Importance of Research}

The pyramid system needs to be watched in Indonesia, especially those using online media, because the offeror will very easily recruit offeree by utilizing social media, by accentuating the brand ambassador, without applying the utmost goodfaith in providing information related to the Forecast of the offered investment, causing the offeree easy to trap for entered in the pyramid scheme.

\section{Brief Literature Review}

1. Closing the space of the offeror who abuses social media in conducting investment promotion ads without applying utmost goodfaith.

2. Enforcing the laws and regulations contained in Law no. 7 of 2014 on Trade, Article 9 which states that distribution business actors are prohibited to apply pyramid scheme system in distributing goods

3. This legal investment practice and pyramid scheme is an unfair business system, promising an abundant profit for its members simply by finding new members without selling real products to the public, if any product is sold, then the product is a cover, camouflage. 
4. Decree of Minister of Industry and Trade Decree No. 73 Year 2000 intended to filter and prevent the emergence of the practice of pyramid schemes or money games, in fact less effective.

5. Some features of the pyramid business trick (both online and offline) can be described as follows:

a Offers quick, easy, lucrative benefits. It's so tempting that someone can not resist.

b Do not have a clear business and effort to increase the value of customer's investment.

c Do not have a product sold, just deposit money. Even if you have a product, usually a waste product alias can not be used.

d Member income is obtained by recruiting new members (downline, investors, customers, etc.), and is not the result of selling the product.

e Claims to have many (even millions of members in the world). The truth is, they have deceived many people in the world.

f Offeror contact (over the phone, email, and social media) you repeatedly. Sometimes using someone else's property to contact you, but it is basically a team to do a trick to follow the pyramid business.

$\mathrm{g}$ The business offers of your relatives who do not realize that they have been snared in a deceitful business.

$h$ The offeror insisted by saying this offer is valid only once, then requested to take the decision immediately, otherwise the opportunity is deemed forfeited.

$i$ Bringing the name of an influential person / brand ambassador to increase the confidence of potential victims.

$\mathrm{j}$ If the business of the form is a stock, the offeror can not explain to which company the money is invested.

6. The need to cultivate public legal awareness of promotional advertising invetations that implement pyramid schemes.

\section{Research Purpose}

This paper aims to analyze:

1. Review the application of good information by emphasizing the principle of utmost good faith in order to increase public awareness of investment promotion ads that implement pyramid schemes.

2. How the role of law in supporting efforts to implement utmost good faith in the delivery of good information.

\section{Method}

This research was conducted by literature study by researching the literature related to the research theme. The method used is a qualitative research method that aims to gain an understanding of the normative and social aspects in examining the appropriate legal framework to be adopted in an effort to review the application of good information by promoting the principle of utmost good faith to inhibit the development of fraudulent practices using pyramid schemes with how to increase public awareness of investment promotion ads. Qualitative methods are also expected to be an appropriate means to identify the role of law in supporting efforts to apply the principle of utmost good faith in the delivery of good information. 


\section{Result and Discussion}

1. Investment Promotion Ads Practices that do not apply the principle of utmost good faith in the delivery of information.

a. Marketing activities are often defined as activities in marketing a product traded by the company and addressed to consumers. However, when viewed the real meaning of marketing is not just selling products alone, but marketing also has an important activity in analyzing and evaluating all the needs and desires of consumers. Marketing also includes all activities within the company. The definition of marketing according to Kotler and amstrong (2012: 28) stating that: “ the process by which companies create value for customer and build strong relationship with customers in order to capture value from customer return". Meanwhile, according to buchari alma (2007: 5) states that "marketing is the emphasis on analysis of market structure, orientation and customer support, and position the company in overseeing the value chain".

Promotion is an important element in the field of marketing, with promotional activities companies can introduce a product or service to consumers, thus consumers will know the existence of a product or service. The function of promotion in helping marketing is to achieve communication goals with consumers. Promotion plays a role in generating good information delivery to consumers of the benefits and advantages of a product or service, so that it can affect the consumer's mind. According to Fandy Tjiptono (2008: 219) states that "promotion is one of the critical success factors of a marketing program to provide information about the existence of a product.
In general, the forms of promotion have the same function, but the form can be differentiated based on the tasks. Some of these tasks can be described as follows: (Fandy Tjiptono, 2008: 222)

1) Personal selling, is a direct (face-toface) communication between the seller and the prospect to introduce a product to the customer.

2) Mass selling, consists of advertising and publicity, which is an approach that uses communication media to convey information to the public at one time.

3) Promosi penjualan, is a form of direct persuasion through the use of various incentives that can be set to stimulate the purchase of the product.

4) Public relations, is a comprehensive communication effort of a company to influence the perceptions, opinions, beliefs, and attitudes of various groups on the company.

5) Direct marketing, is an interactive marketing system, utilizing one or more advertising media to generate measurable responses and / or transactions in any location.

b. A good marketer, should be able to memahmi prospective consumers in all things that affect into the purchasing decision process. Because in understanding consumer behavior in making purchasing decisions there are several important factors that influence each purchase decision. There are several factors that can influence purchasing decisions, such as factors of purchase according to Kotler and Koller (2009: 214), among others, as follows:

1) Cultural factors

a. Culture is the most fundamental determinant of desire and behavior.

b. Sub-cultures, consisting of nationality, religion, racial group and geographical area. Many sub-cultures make up 
important market segments, and marketers often design products and programmers tailored to their needs.

c. Social class, is a relatively homogeneous and permanent division of society, and is structured hierarchically and its members share the same values of interest and behavior.

2) Social factors

a Reference group, a person consists of all groups that have a direct (face-to-face) or indirect effect on a person's attitude or behavior.

b The family, the most important consumer buying organization in the community, has been the object of extensive research.

c Roles and status, roles include activities expected to be performed by a person. Each role produces status, people choose products that can communicate their roles and status in the community.

3) Personal factors

a Age and stage of the life cycle, people buy different goods and services throughout their lives. People's tastes for food, drink, clothing, furniture, and recreation are age-related.

b Employment and economic circumstances, one's work also affects his consumption patterns. Marketers seek to identify a group of professions who have interest in their average products and services.

c Personality and self-concept, personality is a person's psychological characteristics that are different from others that cause a relatively consistent and lasting response to the environment.

d Lifestyle and values, lifestyle is the lifestyle of a person in the world expressed in the activity of his interests and opinions.

4) Psychological factors

a Motivation, a person has many needs at a certain time. Needs will be a motive if didorang up to the level of adequate intenasitas, the motive is the need is enough to encourage someone to act.

b Perception, is a process used by individuals to choose, organize and interpret information to create a meaningful world picture.

c Learning, including changes in the behavior of a person arising from an experience.

d Memory, all the information and experiences that people face as they lead lives can end up in long-term memory.

c. With the presence of social media as a modern technology, of course the way of human life will also experience change. Some changes are more effective and efficient human in obtaining information is not hindered time, place and cost is not too expensive. From the economic side of the increasing public interest in social media, not a few of our society to profit by doing business through social media. Therefore, society will increasingly depend on social media, and this will affect their daily life. Accessing social media at all times has become a new human need to always update information because social media has become a more actual source of information than any other media. (https://pajsindonesia.wordpress.com )

Promotion through social media proved powerful, this is because everyone has social media, and this makes the product easily known in a minimum circle of existing friendship. For larger companies and 
businesses, the power of social media is used to promote products and services, so that many audiences who are able to recognize are also interested in purchasing such products and services. All that thanks to a variety of social media and also various ways that can be used to perform such promotions.

Promotion of investment in its development began to penetrate social media, this is by utilizing public figures that serve as brand ambassador, so often do not inform clearly and detailed forecasts associated with the investment offered. This is a very risky exploited by business actors, to capture consumers, to participate in the business. (Susanto, 2008: 3) d. The principle of utmost good faith implies both sides, reciprocally must underlie the agreement / agreement in good faith. It means not to hide the clear and true explanations that each party needs.

The definitive utmost good faith can be interpreted: "a positive obligation must be voluntary to disclose all material facts completely, clearly and correctly about the risks that will occur, whether asked or not."

1. Promotional forms under the pyramid scheme and how to overcome them.

Here are the forms of promotional advertising through social media, by raising the public figure as a brand ambassador:

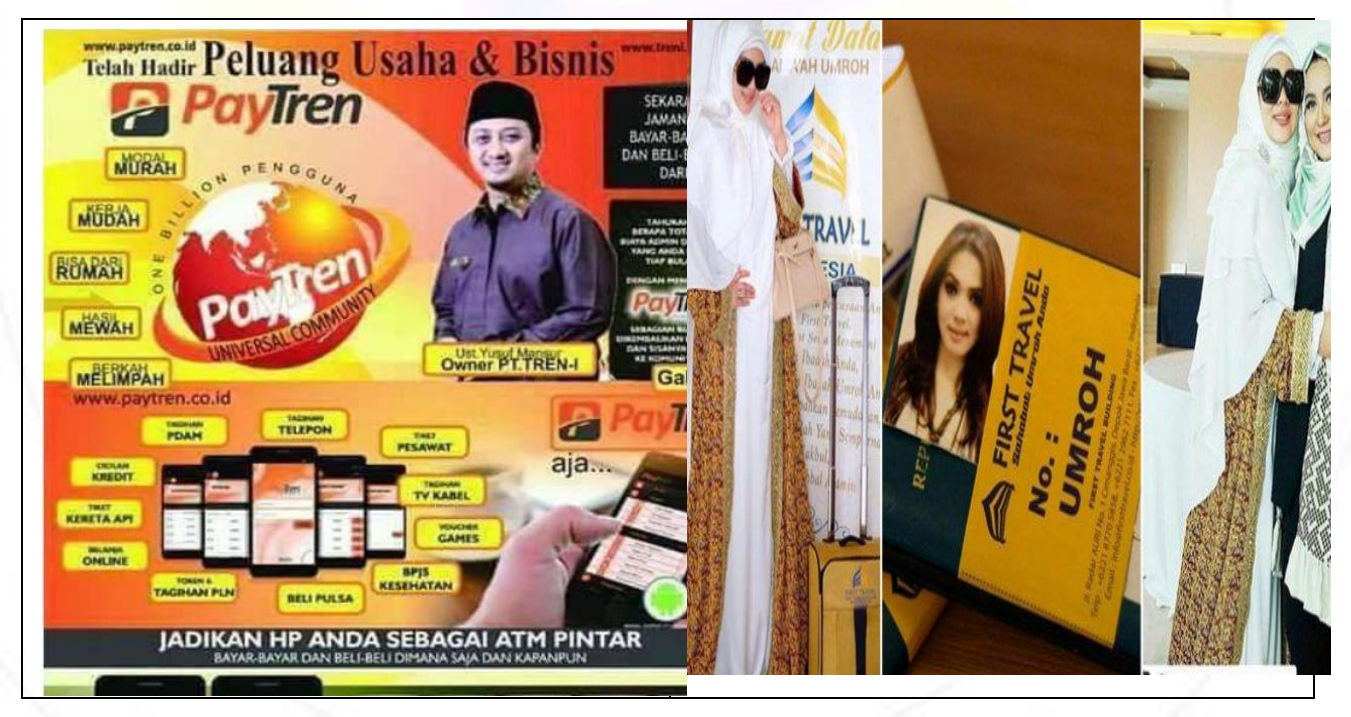

Paytren promotional ads that feature a reputable ustad, in hooking the customer
First Travel promotion ads using instagram social media by appointing an artist / public figure as a brand ambassador. 
a. In Indonesian law, the Pyramid Scheme by disguising the registration fee in the sale of the foredged product is not explicitly prohibited. Law no. 7 of 2014 on trade only mentions a prohibited pyramid scheme is a scheme in which the member's primary income comes from the cost of participation of others. This is different from other countries, let's say the United States has more detailed laws. In the absence of any registration fee a Multi Level Marketing (Andreas Harefa, 1999: 4) can be considered a pyramid scheme and punished, if the product is only purchased by the person who will be a member. Also, this type of MLM can be punished for the promise of a business opportunity that does not come true.

Even so, the following two things are commonly done by MLM pyramid schemes with products that are terapalkan: (www.succesbefore30.co.id)

1) the promised product benefits do not match reality.

2) business opportunities that are heralded when offering a product is just an opportunity on paper that ultimately also does not come true.

Both of these should be able to make the MLM pyramid scheme with the product being stripped, or any practice that no MLM frills, subject to the article in Law no. 8 of 1999 concerning consumer protection, as well as a fraudulent article under Article 378 of the Criminal Code, which declares fraud is an act with the intent to benefit yourself or others unlawfully, by using false or false dignity, with deceit, or set of lies, other people to hand over something to him, or to give up debt or write off accounts receivable.

2. Efforts to prevent the development of business with the pattern of pyramids in Indonesia through social media.

a. Contrary to the basics of the direct selling system and the current code of ethics:

1) Metamorphosis of chain mail system that has been banned in many countries.

2) The rules are very similar to chain letters:

a) Withdraw the registration fee is quite large

b) Products provided by the company are only for the purpose of camouflage, since the emphasis of business on the network format and members is not always required to take the purchased product let alone be trained to resell.

b. Apply law convergence to pyramid scheme business through multi-legal aspect approach, such as:

1) because the structure and the substance contain weaknesses, so the need for empowerment and legal renewal of multi-faceted approach and the application of convergence of legal responsibility.

2) weak legal awareness, so it is necessary to provide legal education to the public, to be able to protect themselves from business investment under the guise of a pyramid scheme and pay more attention to the forecast than the 
investment, and legality rather than to the factor of who becomes the brand ambassador.

3) The double position of the promoter / offeror so that his role will be absurd, so the legal responsibility is difficult given, since the previous offeror is also an offeree, who inheritance invites offeree to join in the investment with the pyramid pattern, therefore required legal convergence by involving multi-faceted aspect to narrow the circulation of business invetation with the pattern of pyramid scheme.

\section{Conclusion}

The development of information is currently running very quickly. with the advent of technological and information developments, society becomes easier in everything including in the market of buying and selling. This increasingly advanced technology should start to be especially cautious in investing advertising that implements pyramid schemes.

Social Media is an online medium, with its users can easily participate, share, and create content and interact. Common and popular social media used today include Instagram, Facebook, Twitter, Path, Ask.fm. In addition, there are also chat applications that facilitate communication with more variants of text, images, phone and video calls such as Line, Whatsapp also BBM. Social media has removed the boundaries in socializing. Thus communication whenever and wherever they are, because there is no limitation of space and time. Today social media has a great influence in one's life.
Some of the traits of pyramid business tricks (both online and offline) that can be known are:

1. Offer quick, easy, and lucrative profits. So tempting until your own noi no threat of refusing it,

2. Not having a clear business and effort to increase the value of customer's investment,

3. Do not have products that are traded, just deposit money. Even if you have a product, usually a waste product alias can not be used,

4. Member income is obtained by recruiting new member (or: downline, investor, client etc), and not from the product selling,

5. Claim has many (even millions of members in the world). The truth: They have been deceiving many people in the world,

6. The person contacted (by phone, email, facebook etc) you repeatedly. Sometimes using other people to contact you, but basically, they are a 'team' to deceive you,

7. It could be that you get this business offer from your friends or relatives who do not realize that they have been snared in a deceptive business,

8. Person urges by saying this offer is valid only once. You are required to take the decision immediately. If not, your 'chances' are forfeited (and various sentences coax, half force others)

9. Sometimes they carry the names of influential people they have perviously joined in their 'business' to increase the confidence of potential victims, showcasing the look of websites and brochures or glossy, thick, neat prospectus and (usually) they desperately claim their business as 'legal and official' business.

10. If it is related to the stock business, they cannot explain to the company where your money will be invested 


\section{References}

Alma, B. (2007). Marketing \& marketing services management. Bandung: Alfabeta.

Civil Code Law Number 7 of 2014 concerning Trade Law Number 8 of 1999 concerning Consumer Protection

Harefa, A (1999). Multi-level marketing. Jakarta: Gramedia Pustaka Utama.

Kotler \& K. (2009). Marketing management, Jilid I, Edisi ke 13, Jakarta: Erlangga.

Kotler, P \& Gary Amstrong. (2012). Principles of marketing Edisi 13, Jilid 1. Jakarta: Erlangga.

Susanto, H. (2008). Consumer rights if harmed. Yogyakarta: Visi Media.

Tjiptono, Fandy. (2008). Marketing Strategy, Edisi 3, Yogyakarta: 